\title{
Assessment of general public satisfaction with public healthcare services
}

\section{in Kedah, Malaysia}

\section{Mohammed Azmi Hassali ${ }^{1}$, Alian A. Alrasheedy ${ }^{1}$, Basyirah Afifah Ab Razak ${ }^{1}$, Saleh Karamah}

\author{
AL-Tamimi1 ${ }^{1}$, Fahad Saleem ${ }^{1}$, Noman Ul Haq ${ }^{1}$, Hisham Aljadhey ${ }^{2}$
}

1. Discipline of Social and Administrative Pharmacy, School of Pharmaceutical Sciences, Universiti Sains

\author{
Malaysia, 11800 Penang, Malaysia
}

2. Medication Safety Research Chair, Clinical Pharmacy Department, College of Pharmacy, King Saud

\section{University, Riyadh, Saudi Arabia}

\section{RESEARCH}

Please cite this paper as: Hassali MA, Alrasheedy $A A, A b$ Razak BA, AL-Tamimi SK, Saleem F, UI Haq N, Aljadhey H. Assessment of General Public Satisfaction with Public Healthcare Services in Kedah, Malaysia. AMJ 2014, 7, 1, 35 44. http://doi.org/10.21767/AMJ.2014.1936.

\section{Corresponding Author:}

Alian A Alrasheedy, BPharm(Hons), MPharm(Clin), BCPS

Discipline of Social and Administrative Pharmacy,

School of Pharmaceutical Sciences,

Universiti Sains Malaysia,

11800 Penang, Malaysia

Email: alian-a@hotmail.com

\section{Abstract}

\section{Background}

Patient satisfaction is considered an essential component of healthcare services evaluation and an additional indicator of the quality of healthcare. Moreover, patient satisfaction may also predict health-related behaviours of patients such as adherence to treatment and recommendations.

\section{Aims}

The study aimed to assess patients' level of satisfaction with public healthcare services and to explore the association between socio-demographic and other study variables and patient satisfaction level.

\section{Method}

A cross-sectional study was conducted using selfadministered questionnaires distributed to a convenience sample of the general public in Kedah, Malaysia.

Results

A total of 435 out of 500 people invited to participate in the study agreed to take part, giving a response rate of 87 per cent. In this study, only approximately half of the participants ( $n=198,45.5$ per cent) were fully satisfied with the current healthcare services. The majority of the participants agreed that doctors had given enough information about their state of health ( $n=222,51$ per cent) and were competent and sympathetic $(n=231,53.1$ per cent). Almost half of the participants ( $n=215,49.5$ per cent) agreed that the doctors took their problems seriously. Only 174 (40 per cent) participants agreed that doctors had spent enough time on their consultation session. Some respondents ( $n=266,61.2$ per cent) agreed that healthcare professionals in the public health sector were highly skilled. The majority of the respondents described amenities, accessibility and facilities available in the public healthcare sector as good or better. In this study, waiting time was significantly associated with patient satisfaction as the results showed that those who waited longer than two hours were less satisfied with the services than those who waited under two hours.

\section{Conclusion}

The study findings showed that approximately half of the respondents were fully satisfied with current healthcare services. In this study, waiting time was the main factor that affected patient satisfaction level. Other factors that influenced satisfaction level included the length of consultation sessions and the process of patient registration. Hence, improvement in the health services that leads to a shorter waiting time may increase the satisfaction level of patients.

\section{Key Words}

Patient satisfaction; quality of service; healthcare services; Malaysia 


\section{What this study adds:}

1. Patients' satisfaction is widely considered as an essential component of healthcare services evaluation and it can be affected by many factors.

2. In this study, waiting time was the main factor that affected patient satisfaction level

3. Improvements in health services that lead to a shorter waiting time may increase the satisfaction level of patients.

\section{Background}

The healthcare delivery system in Malaysia has undergone huge improvements since the country's independence in 1957 and currently a fairly comprehensive range of health services is provided by both public and private sectors. Although healthcare services are provided via a dual system (public and private), the public healthcare sector is the main provider and the Ministry of Health $(\mathrm{MOH})$ is also the main regulatory and policy-making body. For example, approximately 78 per cent of the hospital beds in the country are in public hospitals and about 74 per cent of hospitalised cases in 2008 were admitted to $\mathrm{MOH}$ public hospitals. ${ }^{1}$ The Malaysian quality of life index improved by 15.6 per cent between 1990 and 2007, but to meet the increasing expectations and patient demand for high-quality health care, the tenth Malaysia Plan 2011-15 (10MP) stressed the provision of quality healthcare services and the $\mathrm{MOH}$ has been tasked with ensuring universal access to quality healthcare and to further improve the services via a more efficient and effective healthcare system. ${ }^{1}$

The World Health Organisation (WHO) defines health as 'a state of complete physical, mental and social well-being and not merely the absence of disease or infirmity'. ${ }^{2}$ Therefore, the role of healthcare providers is not merely to cure diseases and provide medical treatment to their patients: today, they are strongly encouraged to deliver a patientcentred service which is closely matched and responsive to patient needs, wants and preferences. ${ }^{3,4}$ Thus, a strong connection between patients and all healthcare providers including physicians, pharmacists, nurses and other staff involved in healthcare provision should be developed not merely to provide treatment but also to cover other areas such as the social, psychological, personal and economic aspects of healthcare provision.

Patients' satisfaction with healthcare services is essential as they are the service consumers. Patient satisfaction can be defined in different ways. ${ }^{5}$ Ware et al. (1983) defined patient satisfaction rating as 'personal evaluation of health care services and providers'. ${ }^{6}$ According to Sitzia and Wood
(1997), satisfaction ratings can reflect the personal preferences of the patient, patient expectations of the healthcare service, and the actual care provided to the patient. ${ }^{7}$ From a psychological perspective, according to Pascoe (1983), patient satisfaction can be defined as 'a health care recipient's reaction to salient aspects of the context, process, and result of their service experience' ${ }^{8}$ Patient satisfaction is considered as an essential component of quality care ${ }^{9}$ and thought to be a good indicator of healthcare quality. ${ }^{10,11}$ Moreover, better patient satisfaction is also believed to be one of the principal reasons why they are likely to comply with the treatment recommendations and advice given by their physicians ${ }^{12,13}$ and an important factor and predictor of patient compliance and adherence. ${ }^{14,15}$ It can also lead to better continuity of care. ${ }^{15}$ Hence, better health outcomes and successful therapy can be achieved.

Thus, studying patient satisfaction is one of the acknowledged methods to evaluate healthcare services and is important for healthcare organisations. ${ }^{16}$ By knowing what patients seek and what they expect of healthcare services, healthcare organisations will be able to tailor services to patient needs and expectations. ${ }^{17}$ Therefore, this study could contribute valuable data useful for improving healthcare systems. Hence, the objectives of this study were to assess patient level of satisfaction with current healthcare services and also to determine the factors that may influence their satisfaction level.

\section{Method}

\section{Study design}

This is a cross-sectional study utilising self-administered questionnaires and was conducted with a convenience sample of the general public in the district of Kulim, Kedah, Malaysia.

\section{Development of the questionnaire/ study tool}

The questionnaire was developed from previous studies and based on an extensive literature review. The face and content validity were checked by a panel of experts consisting of three academics who were familiar with the Malaysian health system and quantitative research. The questionnaire was tested with some members from the target population for its comprehension, understandability and clarity. The results from pilot testing were not included in the main study. The final questionnaire consisted of five sections. The first section included demographic data and also included the patient's health in the last year. It also assessed the patient's last appointment with a health professional and also their waiting time. The second section consisted of eight statements and explored patient 
perceptions of the relationship and interaction with healthcare professionals in the public healthcare system. In this section, participants were asked to respond on a fivepoint Likert scale ranging from strongly agree (1), agree (2), neutral (3), disagree (4) to strongly disagree (5). The third section consisted of six statements and explored patient perceptions of the skills of the healthcare professionals. A five-point Likert scale was also used for this section. The fourth section aimed to explore patient assessment of the amenities, accessibility and facilities of public health care. This section allowed the patients to rank the statements as weak (1), modest (2), good (3), very good (4), or excellent (5). The fifth section consisted of nine statements and was designed to assess the general satisfaction of the patients with public healthcare services. In this section, participants were asked to indicate their agreement on a five-point Likert scale.

\section{Study population and sample size}

The participants in this study were residents of Kulim, a town in the state of Kedah. It is located in the south-east of Kedah bordering on the Penang state to the west. Kulim is a district with 15 smaller sub-districts known as mukim. It has a population of approximately $172,984 .{ }^{18}$ Hence, the minimum effective sample size would be 384 with 95 per cent confidence level and five per cent margin of error calculated with Raosoft ${ }^{\circledR} .{ }^{19}$ Because of the lack of a sampling frame, the number of the sample was increased to 500 respondents in order to minimise the chances of sampling bias and to compensate for non-response.

\section{Data collection}

Self-administered questionnaires were distributed throughout the Kulim area. The people visiting public places such as the shopping mall, night market, photo shops, car service centres, school and college areas, restaurants and so on were approached and invited to participate in the study. Upon approaching potential participants, they were provided with an overview of the study (its objective, the time it takes etc.) and confidentiality of their responses was assured. Moreover, all participants were informed that the participation is strictly voluntary and they can withdraw any time during filling up the questionnaires and they were free not to answer any part of the questionnaire they feel not comfortable with it. The questionnaires were distributed in 2012. The approval to conduct the study was granted by the Discipline of Social and Administrative Pharmacy, School of Pharmaceutical Sciences, Expedited Human Survey Research Committee (Approval number: 002/2012). Furthermore, the declaration of Helsinki was followed during the execution of the study.

\section{Data analysis}

Descriptive and inferential statistics were used to analyse the data. Descriptive statistics included frequency and percentages. The non-parametric Chi-square test was used to measure the association between the variables. For items expected to have small frequencies, defined as fewer than two, or if more than 20 percent of the expected frequencies were fewer than five, the alternative procedure, Fisher's exact test, was used. ${ }^{20}$ The significance level was set at $P$ value less than 0.05. Data analysis was performed with the Statistical Package for Social Sciences (SPSS) version 18 for Windows.

\section{Results}

\section{Demographic data}

A total of 435 out of the 500 people approached agreed to take part in the study, giving a response rate of 87 per cent. A total of 37 per cent $(n=142)$ were in the 25-34 age group. The majority of the participants ( $n=388,89.2$ per cent) were Malay followed by Indian ( $n=23,5.3$ per cent) and Chinese ( $n=18,4.1$ per cent). The majority of the respondents ( $n=$ 313,72 per cent) were university graduates and 23.9 per cent $(n=104)$ of participants held only a high school diploma. Of the respondents 39.5 per cent $(n=172)$ were government employees followed by privately/self-employed ( $n=129$, 29.7 per cent), students ( $n=110,25.3$ per cent), unemployed ( $n=20,4.6$ per cent) and retirees ( $n=4,0.9$ per cent). The majority of the respondents ( $n=252,57.9$ per cent) were married and 40.5 per cent $(n=176)$ were single. Details of the demographic data of the respondents are shown in Table 1.

\section{Patients' perceptions of their relationship and interaction with healthcare professionals in the public healthcare sector}

The questions in this section aimed to explore the perceptions of the participants of their relationship and interaction with healthcare professionals. The majority of the respondents agreed that doctors had given them enough information about their state of health $(n=222,51$ per cent) and that they were competent and sympathetic ( $n=231,53.1$ per cent). Almost half of the respondents agreed that doctors took their problems seriously $(n=215$, 49.5 per cent), they could interact well with the doctors ( $n=250,57.5$ per cent), they had a chance to ask question ( $n=250,57.5$ per cent) and their questions were answered clearly by the doctors ( $n=235,54$ per cent). Some 54.9 per cent $(n=239)$ agreed that pharmacists politely advised them about useful drugs. Almost half of the respondents $(n=211$, 48.5 per cent) gave a neutral response when they were asked if doctors spent enough time on their consultation sessions ( $n=211,48.5$ per cent). There were statistically 
significant associations between waiting time and statements in this section, namely statement one-doctors in government hospitals and clinics take my problem seriously $\left(\chi^{2}=36.267, \mathrm{df}=8, p=<0.001\right)$, statement two- doctors spend enough time on my consultation $\operatorname{session}\left(\chi^{2}=40.665\right.$, $\mathrm{df}=8, p=<0.001)$, statement three- Doctors give enough information about my state of health $\left(\chi^{2}=34.545, \mathrm{df}=8, p=\right.$ $<0.001)$, statement four- doctors have good and kind attitude $\left(\chi^{2}=42.499, \mathrm{df}=8, p=<0.001\right)$, statement five- I can interact well with the doctors $\left(\chi^{2}=26.917, \mathrm{df}=8, p=<\right.$ $0.004)$, statement six- I have a chance to ask questions of the doctor $\left(\chi^{2}=22.255, \mathrm{df}=8, p=<0.004\right)$, statement seven- doctors answer my questions clearly $\left(\chi^{2}=23.628\right.$, df $=8, p=0.003)$ and statement eight- pharmacist gives advice politely to me regarding useful medication $\left(\chi^{2}=17.825, \mathrm{df}=\right.$ $8, p=0.023)$. Waiting time was described as the time between patient registration and departure from hospital. Those who waited for two hours or less were found to be more in agreement with all the above statements than those who waited for more than two hours. The details are shown in Table 2.

\section{Patient perception of skills of healthcare professionals}

The majority of the respondents agreed with all the statements in this section except the one about the efficiency and speed of the registry division to which they ( $n=188,43.2$ per cent) gave a neutral answer. Other statements with which the respondents agreed were: health staff in government hospitals/clinics have good medical skills ( $n=246,56.5$ per cent), professionals like doctors, pharmacists, and support staff in the public healthcare sector are highly skilled ( $n=266,61.2$ per cent), health staff, particularly pharmacists, explained drugs clearly in detail and were easy to understand ( $n=244,56.1$ per cent), test results, treatment, medications, procedures and side-effects were explained in a way that was understandable ( $n=238,54.7$ per cent), and information given by the staff was helpful and useful to the patients ( $n=223,51.3$ per cent). All of these statements are statistically significantly associated with the waiting time of the patients, namely statement one-health staffs in government hospitals/ clinics have good medical skills $\left(\left(\chi^{2}=\right.\right.$ 37.529, df $=8, p=<0.001)$, statement two- test results, treatment, medications, procedures and side effects are explained in a way that is understandable $\left(\chi^{2}=40.007\right.$, df $=8, p=<0.001$ ), statement three-professionals like doctors, pharmacists, and support staff in the public healthcare sector are highly skilled $\left(\chi^{2}=16.599, \mathrm{df}=8, p=0.035\right)$, statement four-health staff, particularly pharmacists, explained about drugs clearly, in detail, and in a way that was easy to understand $\left(\chi^{2}=23.272, \mathrm{df}=8, p=0.003\right)$, statement five- registry division manages my business efficiently and quickly ( $\chi^{2}=33.755, \mathrm{df}=8, p=<0.001$ ) and statement six-Information and advice given by the health staff are very useful and helpful $\left(\chi^{2}=34.125\right.$, df $=8, p=<$ $0.001)$. Those who wait for two hours or under are those who mostly agreed with these statements. With regard to the usefulness and helpfulness of the information given by staff, results showed that this statement was significantly associated not only with waiting time $\left(\chi^{2}=34.125, \mathrm{df}=8, p=\right.$ $<0.001)$ but also with age $\left(\chi^{2}=33.910, \mathrm{df}=16, p=0.002\right)$, race $\left(\chi^{2}=35.102, \mathrm{df}=12, p=<0.001\right)$, status $\left(\chi^{2}=18.864\right.$, df $=8, p=0.009)$, education level $\left(\chi^{2}=21.835, \mathrm{df}=12, p=0.025\right)$ and occupation $\left(\chi^{2}=34.088, \mathrm{df}=16, p=0.003\right)$. The respondents who agreed with this statement were mostly between 25 and 34 years old. They were also mostly Malay, married, university graduates and government employees. Details are provided in Table 3.

Patients' assessment of the amenities, accessibility to and facilities available in the public healthcare sector

In this section, the respondents were asked to rate the amenities and accessibility to and facilities available in the public healthcare sector with scores ranging from weak, modest, good, very good to excellent. The statements included the level of hygiene in the hospitals and clinics, cleanliness of the waiting-room and its facilities, affordability of hospital charges, waiting time at the pharmacy department (for medication) and the follow-up by the hospital or clinic. About half of the participants considered the level of hygiene in hospitals and clinics ( $n=219,50.3$ per cent) and the cleanliness of waiting-room and its facilities ( $n=220,50.6$ per cent) are good. Many of the participants ranked affordability of hospital charges ( $n=199,45.7$ per cent), waiting time at the pharmacy department (for medication) ( $n=208,47.8$ per cent) and the follow-up by their hospital ( $n=194,44.6$ per cent) as good. In this section, only two statements were found to be statistically significantly associated with waiting time. These statements were affordability of the hospital charges $\left(\chi^{2}\right.$ $=22.954, \mathrm{df}=8, p=0.003$ ) and waiting time at the pharmacy department $\left(\chi^{2}=23.499, \mathrm{df}=8, p=0.003\right)$. Respondents who wait for two hours or less were found to be the most likely to rank the statement (waiting time at pharmacy department) as good and the respondents who ranked it as weak are mostly those who wait for more than two hours. Besides waiting time, the affordability of hospital charges was also found to be statistically significantly associated with age $\left(\chi^{2}=32.916, \mathrm{df}=16, p=0.003\right)$, gender $\left(\chi^{2}=9.691\right.$, $\mathrm{df}$ $=4, p=0.046)$ and education level $\left(\chi^{2}=22.110\right.$, df $=12, p$ $=0.019$ ). Respondents in the 25-34 age group formed the majority of those who ranked it as good, followed by 18-24year-old respondents. Respondents in the 25-34 age group were also found to form the majority of those who ranked it 
as very good and excellent compared with other age groups. Female respondents mostly ranked it as good and university graduates were found to form the majority of those who ranked it not only as good but also as very good and excellent. Details are shown in Table 4.

\section{General satisfaction of patients with public healthcare services}

This section consisted of nine statements that reflected the general satisfaction with public healthcare services. The respondents mostly agreed that the hospital staff were always professional ( $n=200,45.9$ per cent) and their privacy was respected by them ( $n=214,46.9$ per cent). They also agreed that they were generally satisfied with the public healthcare services ( $n=198,45.5$ per cent). Most of the respondents selected the neutral score for other statements: they can easily and efficiently make a treatment appointment ( $n=196,45.1$ per cent), they are satisfied with medical check-up ( $n=215,49.4$ per cent), the hospitals staff work well together ( $n=208,47.8$ per cent), the services offered by pharmacy staff met their expectations ( $n=220,50.6$ per cent), the level of care was very good ( $n=217,49.9$ per cent) and the staff are always available when needed ( $n=221,50.8$ per cent). Eight out of nine statements were found to be statistically significantly associated with age. Respondents in the 25-34 age group formed the majority who felt neutral about all these statements. Younger respondents aged 18 to 24 were the most likely to agree that the staff were professional $\left(\chi^{2}\right.$ $=30.017, \mathrm{df}=16, \mathrm{p}=0.007$ ) and their privacy was respected by them $\left(\chi^{2}=30.594, d f=16, p=0.006\right)$. All of these statements were also found to be statistically significantly associated with waiting time. The last statement in this section ('Generally, I am satisfied with the healthcare services in government hospitals or clinics') was found to be statistically significantly associated with waiting time $\left(\chi^{2}\right.$ $=29.270, \mathrm{df}=8, \mathrm{p}=<0.001)$, gender $\left(\chi^{2}=15.043, \mathrm{df}=4, p\right.$ $=0.005)$ and age $\left(\chi^{2}=28.128, \mathrm{df}=16, p=0.012\right)$. Many of those who wait for less than one hour $(n=81,58.70)$ and those who wait for one to two hours ( $n=82,42.93$ per cent) agreed with the statement whereas of those who wait for more than two hours, only 30.19 per cent $(n=35)$ of them agreed with the statement. The detailed responses are shown in Table 5.

\section{Discussion}

Patient satisfaction is considered as one of the indicators of quality healthcare services. It is also important for developing a strong consistent relationship between patients and healthcare professionals. The findings of this study showed that almost half of the participants were satisfied with current healthcare services in public hospitals and clinics. There was a statistically significant association between this finding (e.g., patient satisfaction) and some participants' characteristics such as gender, age and waiting time. The respondents who have to wait for more than two hours are the least satisfied group. Those who wait for less than one hour and between one and two hours, however, displayed a similar satisfaction level with the current public healthcare services. This finding is similar to other studies performed in other Malaysian states, particularly the study conducted by Raja Lexshimi et al. (2009) ${ }^{21}$ at the National University of Malaysia Medical Centre in Kuala Lumpur and Al-Hadad et al. (2010) ${ }^{22}$ study that was conducted in the state of Penang and is congruent with the findings of another study conducted in Chicago, USA by Thompson et al. $(1995)^{23}$ which also found that a long wait time caused patient dissatisfaction with hospital services. Therefore, it may affect the quality of healthcare provided. In our study, there was significant association between age and satisfaction with current services $(p=0.012)$ but no significant association with state of health. In a study conducted by Candlish et al. (1998), elderly patients were the most likely to be satisfied compared with younger patients. ${ }^{24}$ In fact, regarding association between age and patient satisfaction, a review by Dayasiri and Lekamgein (2010), which focused on patient satisfaction in Asian hospitals, showed that only few studies reported an effect of age on the satisfaction while the majority of studies reported no association. ${ }^{25}$ Regarding state of health, Bleich et al. (2009) also reported in their study that patients with bad or moderate health were the least satisfied with the services compared with those who had a good state of health. $^{26}$

Regarding patient satisfaction and employment status of participants, a study by Yunus et al. (2004) found that government and private sector employees were more satisfied with the services provided than were unemployed patients. $^{27}$ In our study, we did not find any significant association between this variable and the patient satisfaction level but that could be because participation of unemployed patients was low (only 4.6 per cent) compared with government and private employees who represented about 39.5 per cent and 29.7 per cent of the study participants, respectively.

Consultation time was also considered one of the main factors that could influence patient satisfaction level. ${ }^{21}$ This study found that most respondents were neutral, neither agreeing nor disagreeing that the time spent by the doctor on the consultation session was adequate. There was a significant association between consultation time and the variables race and waiting time. The study performed in 
Kuala Lumpur by Lexshimi (2009) revealed low patient satisfaction with consultation time. ${ }^{21} \mathrm{~A}$ study by Anderson et al. (2007) found that patients can accept their longer waiting time as long as they feel they get enough time with their physician. ${ }^{28}$ The authors warned, however, that the combination of a short consultation time and long waiting time is toxic in terms of patient satisfaction and this must be avoided by the healthcare providers in particular and by the healthcare system in general.

The patients' views about the amenities and accessibility of the public healthcare sector were also explored in the present study. The examples included in our study were the hygiene of the hospitals and clinics, the cleanliness and facilities available in the waiting-room, and also the followup performed by the public healthcare institutions. In general, the majority of the participants ranked all these aspects as good. These factors may considerably influence patients' general satisfaction with public healthcare services. The findings of Yunus et al.'s (2004) study revealed that there were positive relationships between patients' satisfaction with accessibility, facilities, environment and continuity of care. ${ }^{27}$

Almost half of the respondents in this study stated that doctors in government hospitals and clinics take their health problems seriously. It is reported in the literature that there is a relationship between health staff empathy and patient satisfaction. Parasuraman et al. (1988) found that patient satisfaction will be higher when the perceived empathy is greater. ${ }^{29}$ Also, a study by Rad et al. (2010) found that there is a positive relationship between medical staff empathy and patient satisfaction and they also reported that the relationship between healthcare professionals, particularly that between doctors and patients, could influence patient satisfaction level. ${ }^{30}$ The satisfaction of patients may also lead to a strong relationship with the healthcare professionals. There are many factors that can contribute to a good relationship between both parties, such as the communication skills of the doctors. A study by Abioye Kuteyi et al. (2010) found that doctors' communication skills and information provision contributed positively to patients' satisfaction level. ${ }^{13}$ They also found that good interpersonal and communication skills are important in terms of gaining patients' confidence and accordingly can also improve patients' adherence to treatment. ${ }^{13}$ In our study, the majority of the respondents agreed that they get enough information about their health from doctors and they also have a chance to ask questions which are answered clearly by the doctors. They also agreed that they can interact well with the doctors. More importantly, the findings of this study showed that this relationship is very important in terms of the patient satisfaction level as most of the respondents who agreed with these aspects were more satisfied with the current healthcare services.

In this study, 56.5 per cent $(n=246)$ of the respondents agreed that the health staffs had good medical skills but 47.8 per cent $(n=208)$ of them were neutral about the statement that hospital staff work well together and 42.8 per cent $(n=186)$ of them agreed with the statement. Malott and Ayala (2008) concluded that the main factor that leads to patient satisfaction is a caring and knowledgeable staff. ${ }^{31}$

The patients wanted highly skilled staff that provided them with information. They also wanted healthcare providers to work as one collaborative team and communicate with each other effectively to provide quality care. ${ }^{31}$ Therefore, to ensure the optimal quality of services, healthcare providers should be more aware of and sensitive to patient satisfaction since it is one of the factors that can help to improve the outcome of the treatment given.

The study had some limitations. First, as it used selfadministered questionnaires, illiterate people were not included. Thus, findings cannot be generalised to include them. Second, the majority of the respondents were from the younger age groups and very few respondents were from the geriatric patient group. In addition, the majority of the respondents were Malay. Therefore, this study might not be representative of geriatric patients and other races. Also, it was not possible to compare the reported or perceived waiting time with the actual waiting time to ensure patient perception of waiting time was fairly accurate. Furthermore, the convenience sampling, although inevitable, is another limitation of the study. Hence, the findings might not be generalised to the widerpopulation.

\section{Conclusion}

The study findings showed that approximately half of the respondents were fully satisfied with current healthcare services. In this study, waiting time was the main factor that affected patient satisfaction level. Other factors that influenced the satisfaction level included the length of consultations and the process of patient registration. Hence, improvement of the health services that leads to a shorter waiting time may increase the satisfaction level of patients.

\section{References}

1. Ministry of Health Malaysia. Country Health Plan: 10th Malaysia Plan 2011-2015. [http://www.moh.gov.my/images/gallery/Report/Country_ health.pdf] 
2. Basic Documents, Forty-fifth edition, Supplement, October 2006. Constitution of the World Health Organization. [http://www.wcpt.org/node/47898]

3. Cheraghi-Sohi S, Hole AR, Mead N, McDonald R, Whalley $D$, Bower $P$, Roland $M$. What patients want from primary care consultations: a discrete choice experiment to identify patients' priorities. Ann Fam Med 2008, 6(2):107-115.

4. Laine C, Davidoff F. Patient-centered medicine: A professional evolution. J Am Med Assoc 1996, 275(2):152156.

5. Gill L, White L. A critical review of patient satisfaction. Leadersh Health Serv 2009, 22(1):8-19.

6. Ware JE Jr, Snyder MK, Wright WR, Davies AR. Defining and measuring patient satisfaction with medical care. Eval Program Plann 1983, 6(3-4):247-263.

7. Sitzia J, Wood N. Patient satisfaction: A review of issues and concepts. Soc Sci Med 1997, 45(12):1829-1843.

8. Pascoe GC. Patient satisfaction in primary health care: $A$ literature review and analysis. Eval Program Plann 1983, 6(3-4):185-210.

9. Vinson JM, Rich MW, Sperry JC, Shah AS, McNamara T. Early readmission of elderly patients with congestive heart failure. J Am Geriatr Soc 1990, 38(12):1290-1295.

10. Fenton JJ, Jerant AF, Bertakis KD, Franks P. The cost of satisfaction: A national study of patient satisfaction, health care utilization, expenditures, and mortality. Arch Intern Med 2012, 172(5):405-411.

11. Browne K, Roseman D, Shaller D, Edgman-Levitan S. Analysis \& Commentary: Measuring Patient Experience As A Strategy For Improving Primary Care. Health Aff (Millwood) 2010, 29(5):921-925.

12. Donabedian A. The quality of care: How can it be assessed? JAMA 1988, 260(12):1743-1748.

13. Abioye Kuteyi E, Bello I, Olaleye T, Ayeni I, Amedi M. Determinant of patient satisfaction with physician interaction. SA Fam Pract 2010, 52(6):557-562.

14. Albert G, Hoogstraten J. Satisfaction as a determinant of compliance. Community Dent Oral Epidemiol 1998, 26(2):139-146.

15. Loblaw DA, Bezjak A, Bunston T. Development and testing of a visit-specific patient satisfaction questionnaire: the Princess Margaret Hospital Satisfaction With Doctor Questionnaire. J Clin Oncol 1999,17(6):1931-1938.

16. Mansour AA, Al-Osimy MH. A study of satisfaction among primary health care patients in Saudi Arabia. J Community Health 1993, 18(3):163-173.

17. Sansgiry SS, Jayawant SS. Pharmacy patient-reported satisfaction with health care services offered by health plans, health clinics, and pharmacies In: Medscape Cliggott Publishing; 2005.

18. Taburan Penduduk.

[http://www.mpkk.gov.my/web/guest/population_distribut ion]

19. Raosaft: An online sample size calculator. [http://www.ezsurvey.com/samplesize.html]

20. Dawson B, Trapp R. Basic \& Clinical Biostatistics: Fourth Edition: McGraw-Hill; 2004.

21. Raja Lexshimi RG, Zaleha MI, Shamsul AS, Suriawati G. Patient satisfaction on waiting time and duration of consultation at Orthopedic Clinic, Universiti Kebangsaan Malaysia Medical Centre. Med Health 2009, 4(1):35-46.

22. Al-Haddad MS, Hassali A, Mohamed Ibrahim MI, Shafie AA. PIH17 General public satisfaction toward the provision of health-care delivery by government hospitals and clinics in the state of Penang. Value Health, 2010, 13(7):A542A543.

23. Thompson DA, Yarnold PR. Relating patient satisfaction to waiting time perceptions and expectations: the disconfirmation paradigm. Acad Emerg Med 1995, 2(12):1057-1062.

24. Candlish $P$, Watts $P$, Redman $S$, Whyte $P$, Lowe J. Elderly patients with heart failure: a study of satisfaction with care and quality of life. Int J Qual Health Care 1998, 10(2):141146.

25. Dayasiri MBKC, Lekamge, ELS. Predictors of patient satisfaction with quality of health care in Asian hospitals. Australas Med J, 2010, 3(11): 739-744.

26. Bleich SN, Ozaltin E, Murray CK. How does satisfaction with the health-care system relate to patient experience? Bull World Health Organ 2009, 87(4):271-278.

27. Yunus $M$, Nasir $M$, Nor Afiah $M$, Sherina $M$, Faizah $M$. Patient satisfaction: a comparison between government and private clinics in Mukim Labu, Sepang, Selangor. Malaysian Journal of Public Health Medicine 2004, 4(2):6-11.

28. Anderson RT, Camacho FT, Balkrishnan R. Willing to wait?: the influence of patient wait time on satisfaction with primary care. BMC Health Serv Res 2007, 7:31.

29. Parasuraman A, Zeithaml V, Berry L. SERVQUAL: A Multiple-Item Scale for Measuring Consumer Perceptions of Service Quality. J Retailing 1988, 64(1):12-40.

30. Rad NF, Som A, Zainuddin Y. Service Quality and Patients' Satisfaction in Medical Tourism. World Applied Sciences Journal 2010, 10 (Tourism \& Hospitality):24-30.

31. Malott D, Ayala L. The Root of All Satisfaction: Patients want caregivers who provide information and compassion. In: Satisfaction snapshot. Edited by Grundy T. Australia and New Zealand: Press Ganey Associates, Inc.

\section{ACKNOWLEDGEMENTS}

We would like to thank all the participants in the study for their participation and time.

\section{PEER REVIEW}

Not commissioned. Externally peer reviewed 


\section{CONFLICTS OF INTEREST}

The authors declare that they have no competing interests.

\section{FUNDING}

None

Table 1: Demographic characteristics of study participants ( $n=435)$

\begin{tabular}{|c|c|c|}
\hline Characteristics & Frequency & Percentage \\
\hline $\begin{array}{l}\text { Age } \\
18-24 \\
25-34 \\
35-44 \\
45-54 \\
55-64 \\
\end{array}$ & $\begin{array}{c}142 \\
161 \\
75 \\
46 \\
11\end{array}$ & $\begin{array}{c}32.6 \\
37.0 \\
17.2 \\
10.6 \\
2.5 \\
\end{array}$ \\
\hline $\begin{array}{l}\text { Gender } \\
\text { Male } \\
\text { Female }\end{array}$ & $\begin{array}{l}177 \\
258\end{array}$ & $\begin{array}{l}40.7 \\
59.3\end{array}$ \\
\hline $\begin{array}{l}\text { Race } \\
\text { Malay } \\
\text { Chinese } \\
\text { Indian } \\
\text { Others }\end{array}$ & $\begin{array}{c}388 \\
18 \\
23 \\
6\end{array}$ & $\begin{array}{c}89.2 \\
4.1 \\
5.3 \\
1.4\end{array}$ \\
\hline $\begin{array}{l}\text { Education level } \\
\text { Primary school } \\
\text { Secondary school } \\
\text { College/ university } \\
\text { No formal education }\end{array}$ & $\begin{array}{c}13 \\
104 \\
313 \\
5\end{array}$ & $\begin{array}{c}3.0 \\
23.9 \\
72.0 \\
1.1 \\
\end{array}$ \\
\hline $\begin{array}{l}\text { Occupation } \\
\text { Government } \\
\text { Private/ own } \\
\text { Retiree } \\
\text { Student } \\
\text { Unemployed }\end{array}$ & $\begin{array}{c}172 \\
129 \\
4 \\
110 \\
20 \\
\end{array}$ & $\begin{array}{c}39.5 \\
29.7 \\
0.9 \\
25.3 \\
4.6 \\
\end{array}$ \\
\hline $\begin{array}{l}\text { Status } \\
\text { Single } \\
\text { Married } \\
\text { Separated/widow/widower }\end{array}$ & $\begin{array}{c}176 \\
252 \\
7\end{array}$ & $\begin{array}{c}40.5 \\
57.9 \\
1.6\end{array}$ \\
\hline $\begin{array}{l}\text { Health level (last year) } \\
\text { Good } \\
\text { Modest } \\
\text { Not good } \\
\text { Bad/worst } \\
\end{array}$ & $\begin{array}{c}296 \\
116 \\
20 \\
3 \\
\end{array}$ & $\begin{array}{c}68.0 \\
26.7 \\
4.6 \\
0.7 \\
\end{array}$ \\
\hline $\begin{array}{l}\text { Last time visited doctor } \\
2 \text { months } \\
6 \text { months } \\
12 \text { months } \\
>12 \text { months }\end{array}$ & $\begin{array}{c}169 \\
117 \\
71 \\
78 \\
\end{array}$ & $\begin{array}{c}38.9 \\
26.9 \\
16.3 \\
7.9 \\
\end{array}$ \\
\hline $\begin{array}{l}\text { Waiting time } \\
\text { Less than } 1 \text { hour } \\
\text { Within } 1-2 \text { hours } \\
\text { More than } 2 \text { hours }\end{array}$ & $\begin{array}{l}138 \\
191 \\
106\end{array}$ & $\begin{array}{l}31.7 \\
43.9 \\
24.4\end{array}$ \\
\hline
\end{tabular}


Table 2: Patients' perception of healthcare professional-patient relationship in public healthcare sector

\begin{tabular}{|c|c|c|c|c|c|c|c|c|c|c|c|c|c|c|}
\hline \multirow[b]{2}{*}{ Survey statement } & \multicolumn{5}{|c|}{ Responses, n (\%) } & \multicolumn{9}{|c|}{ Pearson Chi Square Test } \\
\hline & SA & AG & $\mathbf{N}$ & DA & SD & Age & Gender & Race & $\begin{array}{c}\text { Education } \\
\text { level }\end{array}$ & $\begin{array}{c}\text { Occupati } \\
\text { on }\end{array}$ & Status & $\begin{array}{c}\text { Health } \\
\text { level (last } \\
\text { year) }\end{array}$ & \begin{tabular}{l}
\multicolumn{1}{c}{ Last } \\
time \\
visited \\
doctor
\end{tabular} & $\begin{array}{l}\text { Waiting } \\
\text { time }\end{array}$ \\
\hline $\begin{array}{l}\text { 1. Doctors in government hospitals and clinics } \\
\text { take my problem seriously. }\end{array}$ & $\begin{array}{l}32 \\
(7.4) \\
\end{array}$ & $\begin{array}{c}183 \\
(42.1) \\
\end{array}$ & $\begin{array}{c}198 \\
(45.5) \\
\end{array}$ & $\begin{array}{c}20 \\
(4.6) \\
\end{array}$ & $\begin{array}{c}2 \\
(0.5) \\
\end{array}$ & $0.024^{b}$ & 0.658 & $0.038^{\mathrm{b} *}$ & $0.253^{\mathrm{b}}$ & $0.161^{b}$ & $0.110^{\mathrm{b}}$ & $0.516^{\mathrm{b}}$ & $0.873^{\mathrm{b}}$ & $<0.001^{\mathrm{b} *}$ \\
\hline $\begin{array}{l}\text { 2. Doctors spend enough time on my consultation } \\
\text { session. }\end{array}$ & $\begin{array}{c}22 \\
(5.1)\end{array}$ & $\begin{array}{c}152 \\
(34.9) \\
\end{array}$ & $\begin{array}{c}211 \\
(48.5) \\
\end{array}$ & $\begin{array}{c}42 \\
(9.7) \\
\end{array}$ & $\begin{array}{c}8 \\
(1.8) \\
\end{array}$ & $0.090^{\mathrm{b}}$ & 0.126 & $0.006^{\mathrm{b}} *$ & $0.736^{b}$ & $0.770^{\mathrm{b}}$ & $0.246^{b}$ & $0.854^{b}$ & $0.385^{\mathrm{b}}$ & $<0.001 *$ \\
\hline $\begin{array}{l}\text { 3. Doctors give enough information about my } \\
\text { state of health. }\end{array}$ & $\begin{array}{c}30 \\
(6.9)\end{array}$ & $\begin{array}{c}192 \\
(44.1)\end{array}$ & $\begin{array}{c}155 \\
(35.6) \\
\end{array}$ & $\begin{array}{c}50 \\
(11.5) \\
\end{array}$ & $\begin{array}{c}8 \\
(1.8) \\
\end{array}$ & $0.186^{\mathrm{b}}$ & 0.689 & $0.005^{\mathrm{b}} *$ & $0.468^{b}$ & $0.194^{b}$ & $0.013^{\mathrm{b}} *$ & $0.234^{b}$ & $0.328^{\mathrm{b}}$ & $<0.001 *$ \\
\hline 4. Doctors have good and kind attitude. & $\begin{array}{c}35 \\
(8.0)\end{array}$ & $\begin{array}{c}196 \\
(45.1)\end{array}$ & $\begin{array}{c}173 \\
(39.8)\end{array}$ & $\begin{array}{c}29 \\
(6.7)\end{array}$ & $\begin{array}{c}2 \\
(0.5)\end{array}$ & $0.007^{\mathrm{b}} *$ & $0.020^{*}$ & $0.130^{b}$ & $0.326^{\mathrm{b}}$ & $0.248^{b}$ & $0.193^{\mathrm{b}}$ & $0.020^{\mathrm{b}} *$ & $0.128^{\mathrm{b}}$ & $<0.001 *$ \\
\hline 5. I can interact well with the doctors. & $\begin{array}{c}38 \\
(8.7)\end{array}$ & $\begin{array}{c}212 \\
(48.7) \\
\end{array}$ & $\begin{array}{c}162 \\
(37.2) \\
\end{array}$ & $\begin{array}{c}19 \\
(4.4) \\
\end{array}$ & \begin{tabular}{|c|c|}
4 \\
$(0.9)$ \\
\end{tabular} & $0.131^{b}$ & $0.049^{*}$ & $0.013^{\mathrm{b}} *$ & $0.807^{b}$ & $0.320^{\mathrm{b}}$ & $0.320^{\mathrm{b}}$ & $0.348^{\mathrm{b}}$ & $0.629^{\mathrm{b}}$ & $<0.001^{b_{*}}$ \\
\hline 6. I have a chance to ask questions of the doctor. & $\begin{array}{c}47 \\
(10.8) \\
\end{array}$ & $\begin{array}{c}203 \\
(46.7) \\
\end{array}$ & $\begin{array}{c}144 \\
(33.1) \\
\end{array}$ & $\begin{array}{c}33 \\
(7.6) \\
\end{array}$ & \begin{tabular}{|c|c|}
8 \\
$(1.8)$
\end{tabular} & $0.141^{\mathrm{b}}$ & $0.015^{*}$ & $0.535^{\mathrm{b}}$ & $0.960^{\mathrm{b}}$ & $0.250^{b}$ & $0.120^{\mathrm{b}}$ & $0.027^{\mathrm{b}} *$ & 0.062 & $0.004 *$ \\
\hline 7. Doctors answer my questions clearly. & \begin{tabular}{|c|c|}
45 \\
$(10.3)$ \\
\end{tabular} & $\begin{array}{c}190 \\
(43.7) \\
\end{array}$ & $\begin{array}{c}163 \\
(37.5) \\
\end{array}$ & $\begin{array}{c}33 \\
(7.6) \\
\end{array}$ & $\begin{array}{c}4 \\
(0.9) \\
\end{array}$ & $0.006^{\mathrm{b}} *$ & 0.163 & $0.375^{b}$ & $0.070^{\mathrm{b}}$ & $0.086^{\mathrm{b}}$ & $0.142^{b}$ & $0.288^{\mathrm{b}}$ & 0.399 & $0.003 *$ \\
\hline $\begin{array}{l}\text { 8. Pharmacist gives advice politely to me } \\
\text { regarding useful medication. }\end{array}$ & \begin{tabular}{|c|c|}
61 \\
$(14.0)$ \\
\end{tabular} & $\begin{array}{c}178 \\
(40.9) \\
\end{array}$ & $\begin{array}{c}152 \\
(34.9) \\
\end{array}$ & $\begin{array}{c}39 \\
(9.0)\end{array}$ & $\begin{array}{c}5 \\
(1.1) \\
\end{array}$ & $0.003^{\mathrm{b}} *$ & 0.218 & $0.317^{b}$ & $0.210^{\mathrm{b}}$ & $0.027^{\mathrm{b}} *$ & $0.052^{\mathrm{b}}$ & $0.944^{b}$ & $0.021^{*}$ & $0.023 *$ \\
\hline
\end{tabular}

$S A=S t r o n g l y$ Agree, $A=$ Agree, $N=$ Neutral, $D A=$ Disagree and $S D=$ Strongly Disagree ${ }^{b}$ Fisher exact test * Statistically significant

Table 3: Patients' perception of professional skills

\begin{tabular}{|c|c|c|c|c|c|c|c|c|c|c|c|c|c|c|}
\hline \multirow[b]{2}{*}{ Survey statement } & \multicolumn{5}{|c|}{ Responses, n (\%) } & \multicolumn{9}{|c|}{ Pearson Chi Square Test } \\
\hline & SA & AG & $\mathbf{N}$ & DA & SD & Age & Gender & Race & $\begin{array}{c}\text { Education } \\
\text { level }\end{array}$ & $\begin{array}{c}\text { Occupati } \\
\text { on }\end{array}$ & Status & $\begin{array}{c}\text { Health } \\
\text { level (last } \\
\text { year) }\end{array}$ & $\begin{array}{l}\text { Last time } \\
\text { visited } \\
\text { doctor }\end{array}$ & $\begin{array}{l}\text { Waiting } \\
\text { time }\end{array}$ \\
\hline $\begin{array}{l}\text { 1. Health staffs in government hospitals/ clinics } \\
\text { have good medical skills. }\end{array}$ & $\begin{array}{c}37 \\
(8.5)\end{array}$ & $\begin{array}{l}209 \\
(48)\end{array}$ & $\begin{array}{c}159 \\
(36.6)\end{array}$ & $\begin{array}{c}29 \\
(6.7)\end{array}$ & $\begin{array}{c}1 \\
(0.2)\end{array}$ & $0.161^{b}$ & 0.535 & $0.656^{\mathrm{b}}$ & $0.307^{\mathrm{b}}$ & $0.095^{\mathrm{b}}$ & $0.250^{\mathrm{b}}$ & $0.470^{\mathrm{b}}$ & $0.858^{\mathrm{b}}$ & $<0.001^{*}$ \\
\hline $\begin{array}{l}\text { 2. Test results, treatment, medications, procedures } \\
\text { and side effects are explained in a way that is } \\
\text { understandable. }\end{array}$ & $\begin{array}{c}40 \\
(9.2)\end{array}$ & $\begin{array}{c}198 \\
(45.5)\end{array}$ & $\begin{array}{c}146 \\
(33.6)\end{array}$ & $\begin{array}{c}47 \\
(10.8)\end{array}$ & $\begin{array}{c}4 \\
(0.9)\end{array}$ & $0.165^{b}$ & 0.373 & $0.017^{\mathrm{b} *}$ & $0.245^{\mathrm{b}}$ & $0.049^{b^{*}}$ & $0.077^{\mathrm{b}}$ & $0.357^{\mathrm{b}}$ & 0.857 & $<0.001^{*}$ \\
\hline $\begin{array}{l}\text { 3. Professionals like doctors, pharmacists, and } \\
\text { support staff in the public healthcare sector are } \\
\text { highly skilled. }\end{array}$ & $\begin{array}{l}39 \\
(9)\end{array}$ & $\begin{array}{c}227 \\
(52.2)\end{array}$ & $\begin{array}{c}131 \\
(30.1)\end{array}$ & $\begin{array}{c}36 \\
(8.3)\end{array}$ & $\begin{array}{c}2 \\
(0.5)\end{array}$ & $\begin{array}{c}<0.001 \\
b *\end{array}$ & 0.059 & $0.096^{\mathrm{b}}$ & $0.548^{\mathrm{b}}$ & $0.040^{b^{*}}$ & $0.202^{\mathrm{b}}$ & $0.733^{\mathrm{b}}$ & 0.597 & $0.035^{*}$ \\
\hline $\begin{array}{l}\text { 4. Health staff, particularly pharmacists, explained } \\
\text { about drugs clearly, in detail, and in a way that } \\
\text { was easy to understand. }\end{array}$ & $\begin{array}{c}50 \\
(11.5)\end{array}$ & $\begin{array}{c}194 \\
(44.6)\end{array}$ & $\begin{array}{c}156 \\
(35.9)\end{array}$ & $\begin{array}{c}31 \\
(7.1)\end{array}$ & $\begin{array}{c}4 \\
(0.9)\end{array}$ & $0.154^{\mathrm{b}}$ & 0.534 & $0.172^{\mathrm{b}}$ & $0.372^{b}$ & $0.109^{b}$ & $0.463^{\mathrm{b}}$ & $0.501^{\mathrm{b}}$ & 0.914 & $0.003 *$ \\
\hline $\begin{array}{l}5 . \text { Registry division manages my business } \\
\text { efficiently and quickly. }\end{array}$ & $\begin{array}{c}44 \\
(10.1)\end{array}$ & $\begin{array}{c}123 \\
(28.3)\end{array}$ & $\begin{array}{c}188 \\
(43.2)\end{array}$ & $\begin{array}{c}65 \\
(14.9)\end{array}$ & $\begin{array}{c}15 \\
(3.4)\end{array}$ & $0.014^{\mathrm{b} *}$ & 0.095 & $0.043^{\mathrm{b} *}$ & $0.476^{\mathrm{b}}$ & $0.008^{\mathrm{b} *}$ & $0.779^{\mathrm{b}}$ & $0.927^{b}$ & 0.327 & $<0.001^{*}$ \\
\hline $\begin{array}{l}\text { 6. Information and advice given by the health staff } \\
\text { are very useful and helpful. }\end{array}$ & $\begin{array}{c}36 \\
(8.3)\end{array}$ & $\begin{array}{l}187 \\
(43)\end{array}$ & $\begin{array}{c}175 \\
(40.2)\end{array}$ & $\begin{array}{c}33 \\
(7.6)\end{array}$ & $\begin{array}{c}4 \\
(0.9)\end{array}$ & $0.002^{\mathrm{b}} *$ & 0.579 & $0.001^{\mathrm{b} *}$ & $0.025^{\mathrm{b}} *$ & $0.003^{\mathrm{b} *}$ & $0.009^{\mathrm{b} *}$ & $0.685^{\mathrm{b}}$ & 0.600 & $<0.001^{*}$ \\
\hline
\end{tabular}

$S A=$ Strongly Agree, $A=$ Agree, $N=$ Neutral, $D A=$ Disagree and $S D=$ Strongly Disagree ${ }^{b}$ Fisher exact test * Statistically significant

Table 4: Patients' assessment of the amenities, accessibility to and facilities available in public healthcare sector

\begin{tabular}{|c|c|c|c|c|c|c|c|c|c|c|c|c|c|c|}
\hline \multirow[b]{2}{*}{ Survey statement } & \multicolumn{3}{|c|}{$\begin{array}{c}\text { Responses, } \mathrm{n} \\
(\%)\end{array}$} & \multicolumn{11}{|c|}{ Pearson Chi Square Test } \\
\hline & WK & MD & GD & VG & EXC & Age & Gender & Race & $\begin{array}{c}\text { Education } \\
\text { level }\end{array}$ & pccupation & Status & $\begin{array}{c}\text { Health } \\
\text { level (last } \\
\text { year) }\end{array}$ & $\begin{array}{r}\text { Last time } \\
\text { visited } \\
\text { doctor }\end{array}$ & $\begin{array}{c}\text { Waiting } \\
\text { time }\end{array}$ \\
\hline $\begin{array}{l}\text { 1. Hygiene in hospitals and government clinics: } \\
\text { wards, toilets, environment, etc. }\end{array}$ & $\begin{array}{l}22 \\
(5.1)\end{array}$ & $\begin{array}{l}114 \\
(26.2) \\
\end{array}$ & $\begin{array}{c}219 \\
(50.3)\end{array}$ & $\begin{array}{c}65 \\
(14.9)\end{array}$ & $\begin{array}{l}15 \\
(3.4)\end{array}$ & $0.857^{\mathrm{b}}$ & $0.023 *$ & $0.098^{\mathrm{b}}$ & $0.648^{\mathrm{b}}$ & $0.725^{\mathrm{b}}$ & $0.615^{\mathrm{b}}$ & $0.732^{\mathrm{b}}$ & $0.641^{\mathrm{b}}$ & 0.904 \\
\hline $\begin{array}{l}\text { 2. Cleanliness, procedures and facilities in the } \\
\text { waiting-room like seating, reading material, etc. }\end{array}$ & $\begin{array}{l}19 \\
(4.4)\end{array}$ & \begin{tabular}{|c|}
126 \\
$(29)$
\end{tabular} & $\begin{array}{c}220 \\
(50.6)\end{array}$ & $\begin{array}{c}49 \\
(11.3)\end{array}$ & $\begin{array}{l}21 \\
(4.8)\end{array}$ & $0.682^{b}$ & $0.028^{*}$ & $0.029^{\mathrm{b}} *$ & $0.821^{\mathrm{b}}$ & $0.489^{b}$ & $0.742^{\mathrm{b}}$ & $0.115^{\mathrm{b}}$ & 0.217 & 0.383 \\
\hline 3. Affordability of public sector hospitals' charges. & $\begin{array}{c}5 \\
(1.1) \\
\end{array}$ & $\begin{array}{c}62 \\
(14.3) \\
\end{array}$ & $\begin{array}{c}199 \\
(45.7) \\
\end{array}$ & \begin{tabular}{|c|}
108 \\
$(24.8)$
\end{tabular} & \begin{tabular}{|c|}
61 \\
$(14)$ \\
\end{tabular} & $0.003^{\mathrm{b} *}$ & $0.046^{*}$ & $0.052^{\mathrm{b}}$ & $0.019^{\mathrm{b}} *$ & $0.522^{b}$ & $0.928^{b}$ & $0.960^{6}$ & 0.303 & $0.003^{*}$ \\
\hline $\begin{array}{l}\text { 4. Waiting time for medication at the pharmacy } \\
\text { department. }\end{array}$ & $\begin{array}{c}40 \\
(9.2)\end{array}$ & \begin{tabular}{|l|}
129 \\
$(29.7)$
\end{tabular} & $\begin{array}{c}208 \\
(47.8)\end{array}$ & $\begin{array}{c}52 \\
(12)\end{array}$ & $\begin{array}{c}6 \\
(1.4)\end{array}$ & $0.375^{\mathrm{b}}$ & $0.002 *$ & $0.122^{b}$ & $0.114^{\mathrm{b}}$ & $0.001^{\mathrm{b}} *$ & $0.958^{\mathrm{b}}$ & $0.343^{b}$ & $0.035^{*}$ & $0.003 *$ \\
\hline $\begin{array}{l}\text { 5. The public healthcare system always checks on } \\
\text { my health status. }\end{array}$ & $\begin{array}{c}52 \\
(12)\end{array}$ & $\begin{array}{l}145 \\
(33.3)\end{array}$ & $\begin{array}{c}194 \\
(44.6)\end{array}$ & $\begin{array}{c}38 \\
(8.7)\end{array}$ & $\begin{array}{c}6 \\
(1.4)\end{array}$ & $0.461^{b}$ & 0.221 & $0.171^{\mathrm{b}}$ & $0.653^{b}$ & $0.005^{\mathrm{b}} *$ & $0.137^{b}$ & $0.726^{\mathrm{b}}$ & 0.376 & 0.133 \\
\hline
\end{tabular}

$W K=$ Week, $M D=$ Medium, $G D=$ Good, $V G=$ Very Good and EXC $=$ Excellent ${ }^{b}$ Fisher exact test ${ }^{*}$ Statistically significant . 
Table 5: General satisfaction of patients with public healthcare services

\begin{tabular}{|c|c|c|c|c|c|c|c|c|c|c|c|c|c|c|}
\hline \multirow[b]{2}{*}{ Survey statement } & \multicolumn{5}{|c|}{ Responses, n (\%) } & \multicolumn{9}{|c|}{ Pearson Chi Square Test } \\
\hline & SA & AG & $\mathbf{N}$ & DA & SD & Age & Gender & Race & $\begin{array}{c}\text { Education } \\
\text { level }\end{array}$ & Occupation & Status & $\begin{array}{c}\text { Health } \\
\text { level } \\
\text { (last } \\
\text { year) }\end{array}$ & $\begin{array}{c}\text { Last time } \\
\text { visited } \\
\text { doctor }\end{array}$ & $\begin{array}{c}\text { Waiting } \\
\text { time }\end{array}$ \\
\hline 1. The hospital staff is always professional. & $\begin{array}{c}18 \\
(4.1) \\
\end{array}$ & $\begin{array}{c}182 \\
(41.8)\end{array}$ & $\begin{array}{c}193 \\
(44.4)\end{array}$ & $\begin{array}{c}32 \\
(7.4)\end{array}$ & $\begin{array}{c}10 \\
(2.3) \\
\end{array}$ & $0.007^{\mathrm{b}}$ & 0.183 & $0.470^{\mathrm{b}}$ & $0.272^{\mathrm{b}}$ & $0.138^{\mathrm{b}}$ & $0.249^{\mathrm{b}}$ & $0.119^{b}$ & $0.350^{\mathrm{b}}$ & $<0.001^{\mathrm{b}} *$ \\
\hline $\begin{array}{l}\text { 2. I can easily make an appointment to get } \\
\text { treatment. }\end{array}$ & $\begin{array}{c}22 \\
(5.1)\end{array}$ & $\begin{array}{c}172 \\
(39.5)\end{array}$ & $\begin{array}{c}196 \\
(45.1)\end{array}$ & $\begin{array}{c}36 \\
(8.3)\end{array}$ & $\begin{array}{c}9 \\
(2.1)\end{array}$ & $0.017^{\mathrm{b}}$ & 0.462 & $0.137^{\mathrm{b}}$ & $0.545^{\mathrm{b}}$ & $0.082^{\mathrm{b}}$ & $0.049^{\mathrm{b}} *$ & $0.512^{\mathrm{b}}$ & $0.213^{\mathrm{b}}$ & $0.001 *$ \\
\hline 3. I'm very satisfied with my medical check-up. & $\begin{array}{c}24 \\
(5.5)\end{array}$ & \begin{tabular}{|c|}
158 \\
$(36.3)$
\end{tabular} & $\begin{array}{c}215 \\
(49.4)\end{array}$ & $\begin{array}{c}30 \\
(6.9)\end{array}$ & \begin{tabular}{|c|}
8 \\
$(1.8)$
\end{tabular} & $0.012^{\mathrm{b}}$ & $0.015^{*}$ & $0.154^{\mathrm{b}}$ & $0.252^{b}$ & $0.009^{\mathrm{b}} *$ & $0.036^{\mathrm{b} *}$ & $0.043^{\mathrm{b} *}$ & $0.155^{\mathrm{b}}$ & $0.002 *$ \\
\hline 4. Hospital staffs always work well together. & $26(6)$ & $\begin{array}{c}160 \\
(36.8)\end{array}$ & $\begin{array}{c}208 \\
(47.8)\end{array}$ & $\begin{array}{l}35 \\
(8)\end{array}$ & $\begin{array}{c}6 \\
(1.4)\end{array}$ & $0.001^{\mathrm{b}}$ & $0.010^{*}$ & $0.292^{b}$ & $0.525^{\mathrm{b}}$ & $0.003^{b_{*}}$ & $0.287^{\mathrm{b}}$ & $0.424^{\mathrm{b}}$ & $0.066^{\mathrm{b}}$ & $0.024 *$ \\
\hline $\begin{array}{l}\text { 5. Service by pharmacy staff met my expectations } \\
\text { overall. }\end{array}$ & $26(6)$ & $\begin{array}{c}151 \\
(34.7)\end{array}$ & $\begin{array}{c}220 \\
(50.6)\end{array}$ & $\begin{array}{c}32 \\
(7.4)\end{array}$ & $\begin{array}{c}6 \\
(1.4)\end{array}$ & $0.030^{\mathrm{b}}$ & 0.198 & $0.086^{\mathrm{b}}$ & $0.086^{\mathrm{b}}$ & $0.122^{b}$ & $0.157^{b}$ & $0.786^{\mathrm{b}}$ & $0.035^{\mathrm{b} *}$ & $0.045^{*}$ \\
\hline $\begin{array}{l}\text { 6. Levels of care in the public healthcare centre are } \\
\text { very good. }\end{array}$ & $\begin{array}{c}19 \\
(4.4)\end{array}$ & $\begin{array}{l}174 \\
(40)\end{array}$ & $\begin{array}{c}217 \\
(49.9)\end{array}$ & $\begin{array}{c}18 \\
(4.1)\end{array}$ & $\begin{array}{c}7 \\
(1.6)\end{array}$ & $0.082^{b}$ & 0.232 & $0.052^{\mathrm{b}}$ & $0.864^{\mathrm{b}}$ & $0.423^{\mathrm{b}}$ & $0.203^{\mathrm{b}}$ & $0.192^{b}$ & $0.334^{\mathrm{b}}$ & $0.006^{\mathrm{b}} *$ \\
\hline 7. Hospital staffs ensure my privacy is respected. & $\begin{array}{c}30 \\
(4.6)\end{array}$ & $\begin{array}{c}184 \\
(42.3)\end{array}$ & $\begin{array}{c}179 \\
(41.1)\end{array}$ & $\begin{array}{l}35 \\
(8)\end{array}$ & $\begin{array}{c}7 \\
(1.6)\end{array}$ & $0.006^{\mathrm{b}}$ & 0.122 & $0.586^{\mathrm{b}}$ & $0.677^{\mathrm{b}}$ & $0.093^{\mathrm{b}}$ & $0.409^{b}$ & $0.145^{\mathrm{b}}$ & $0.239^{\mathrm{b}}$ & $<0.001^{*}$ \\
\hline $\begin{array}{l}\text { 8. Hospital staffs are always available when I need } \\
\text { them. }\end{array}$ & $\begin{array}{c}20 \\
(4.6)\end{array}$ & $\begin{array}{c}125 \\
(28.7)\end{array}$ & $\begin{array}{c}221 \\
(50.8)\end{array}$ & $\begin{array}{c}56 \\
(12.9)\end{array}$ & $\begin{array}{l}13 \\
(3)\end{array}$ & $0.027^{b}$ & 0.203 & $0.091^{\mathrm{b}}$ & $0.847^{\mathrm{b}}$ & $0.133^{b}$ & $0.519^{b}$ & $0.855^{\mathrm{b}}$ & $0.724^{b}$ & $<0.001^{*}$ \\
\hline $\begin{array}{l}\text { 9. Generally, I am satisfied with the healthcare } \\
\text { services in government hospitals / clinics. }\end{array}$ & $\begin{array}{c}25 \\
(5.7)\end{array}$ & $\begin{array}{c}173 \\
(39.8)\end{array}$ & $\begin{array}{c}195 \\
(44.8)\end{array}$ & $\begin{array}{c}34 \\
(7.8)\end{array}$ & $\begin{array}{c}8 \\
(1.8)\end{array}$ & $0.012^{\mathrm{b}}$ * & $0.005^{*}$ & $0.090^{\mathrm{b}}$ & $0.159^{b}$ & $0.179^{b}$ & $0.277^{5}$ & $0.379^{b}$ & $0.690^{b}$ & $<0.001^{*}$ \\
\hline
\end{tabular}

$S A=S$ trongly Agree, $A=$ Agree, $N=$ Neutral, $D A=$ Disagree and $S D=$ Strongly Disagree ${ }^{b}$ Fisher exact test * Statistically significant 